\title{
O GRUPO SANTA BÁRBARA (EDIACARANO) NA SUB-BACIA CAMAQUÃ CENTRAL, RS: ESTRATIGRAFIA E SISTEMAS DEPOSICIONAIS
}

\author{
GELSON LUÍS FAMBRINI ${ }^{1}$, LILIANE JANIKIAN ${ }^{2}$, RENATO PAES DE ALMEIDA ${ }^{3}$ \& \\ ANTONIO ROMALINOS. FRAGOSO-CESAR ${ }^{3}$
}

\begin{abstract}
RESUMO As exposições do Grupo Santa Bárbara (Ediacarano) na Sub-Bacia Camaquã Central são representadas por uma sucessão de depósitos arenosos e rítmicos marinhos/transicionais e depósitos conglomeráticos de leques aluviais, que compõem ciclos progradacionais-retrogradacionais. Nesta sub-bacia, o Grupo Santa Bárbara apresenta mais de $2000 \mathrm{~m}$ de espessura, com excelentes exposições nas regiões das Minas do Camaquã e de Bom Jardim.

Estudos estratigráficos de paleoambientes, paleocorrentes e de proveniência realizados nestas regiões possibilitaram a seguinte subdivisão do Grupo Santa Bárbara na Sub-Bacia Camaquã Central, a partir da base: (i) Formação Passo da Capela: unidade areno-siltítica subdividida em turbiditos de franjas externas de leque submarino (Outer-fan), e turbiditos de franjas internas a externas de leque submarino (Inner-Fan a Outer-fan); (ii) Formação Seival: tempestitos de costa-afora e depósitos litorâneos e de planície de marés; (iii) Formação Rincão do Mouras: unidade conglomerática formada por depósitos de leques aluviais e de riops entrelaçados e (iv) Formação João Dias: composta por depósitos litorâneos de antepraia e de face litorânea e de tempestitos de face litorânea. Estes estudos permitiram ainda o reconhecimento de uma notável correlação entre as unidades encontradas nestas regiões legitimando, desta forma, a proposta de englobar os depósitos da região das Minas do Camaquã, classicamente relacionadas à Formação Arroio dos Nobres, no redefinido Grupo Santa Bárbara.
\end{abstract}

Palavras-Chave: Grupo Santa Bárbara, Bacia do Camaquã, estratigrafia, análise de fácies, Ediacarano

\begin{abstract}
THE SANTA BÁRBARA GROUP (EDIACARAN) IN THE CENTRAL CAMAQUÃ SUB-BASIN, RIO GRANDE DO SUL, BRAZIL: stratigraPHY AND DEPOSITIONAL SYSTEMS In the Central Camaquã Sub-basin, the Santa Bárbara Group (Ediacaran) is over 2,000 m thick, being well exposed in the Minas do Camaquã and Bom Jardim regions. The group is represented by a succession of marine to coastal sandstones and rhythmites and alluvial fan conglomerates, disposed in progradationalretrogrational cycles. Detailed stratigraphic studies of paleoenvironments, paleocurrents and provenance have lead to the subdivision of the Santa Bárbara Group, in the Central Camaquã Sub-basin, into four formations: (i) Passo da Capela Formation: silty-sandy unit composed of outer- and inner-submarine fan turbidites; (ii) Seival Formation: offshore tempestites and coastal deposits, including tidal flat deposits; (iii) Rincão dos Mouras Formation: alluvial fan and braided river pebbly unit and (iv) João Dias Formation: foreshore and shoreface coastal deposits.

These studies have permitted the detailed correlation between the Minas do Camaquã and Bom Jardim regions, thus supporting the proposition of including, in the here defined Santa Bárbara Group, the deposits exposed in the Minas do Camaquã region, traditionally reported to the Arroio dos Nobres Formation.
\end{abstract}

Keywords: Santa Bárbara group, Camaquã Basin, stratigraphy, facies analysis, Ediacaran

INTRODUÇÃO Sobre o embasamento metamórfico do Rio Grande do Sul ocorrem coberturas sedimentares e vulcanosedimentares reunidas no Supergrupo Camaquã (EdiacaranoEopaleozóico), redefinido por Fragoso-Cesar et al. (2003). Essa unidade atinge espessura significativamente superior a $6.000 \mathrm{~m} \mathrm{e}$ é constituída pelas seguintes unidades: (i) Grupo Maricá - unidade basal, gerada em ambientes marinhos e aluviais, (ii) Grupo Bom Jardim - gerado em ambientes continentais subaquáticos e subaéreos, com atividades vulcânicas concomitantes, (iii) Formação Acampamento Velho - rochas vulcanogênicas colocadas em ambientes subaéreos, (iv) Grupo Santa Bárbara - formada em ambientes aluviais e marinho costeiro e profundo, (v) Grupo Guaritas - preenchido por sedimentos aluviais e eólicos e (vi) e Suíte Ro- deio Velho - intrusões máficas rasas (Fig. 1).

O Supergrupo Camaquã aflora em três sub-bacias principais de direção preferencial NNE-SSW denominadas Camaquã Ocidental, Central e Oriental, atualmente separadas pelos altos de embasamento de Caçapava do Sul, a oeste, e da Serra das Encantadas, a leste. O Grupo Santa Bárbara apresenta exposições em todas estas sub-bacias e foi gerado após as atividades vulcânicas da Formação Acampamento Velho.

A Sub-Bacia Camaquã Central abrange, a norte do rio Camaquã, as ocorrências das regiões das Minas do Camaquã, famosa por alojar as mineralizações de cobre, aparentemente esgotadas, e de Bom Jardim, ambas no município de Caçapava do Sul, estado do Rio Grande do Sul. A sul deste rio compreende as ocorrências das

1- Departamento de Geologia, Centro de Tecnologia e Geociências, Universidade Federal de Pernambuco, Avenida Acadêmico Hélio Ramos s/n, sala 510, Recife, PE, CEP: 50.740-530, fone: (+55 81) 2126-8240 ramal 34, FAX: (+55 81) 2126-8234. E-mail: gelson.fambrini@ufpe.br 2 - Pós-Graduação em Geologia Sedimentar, Instituto de Geociências, Universidade de São Paulo, São Paulo, Bolsista da FAPESP (01/01439-9). Email: lijanikian@yahoo.com.br

3 - Departamento de Geologia Sedimentar e Ambiental, Instituto de Geociências, Universidade de São Paulo, São Paulo, SP. E-mail: rpalmeid@usp.br, romalino@usp.br 


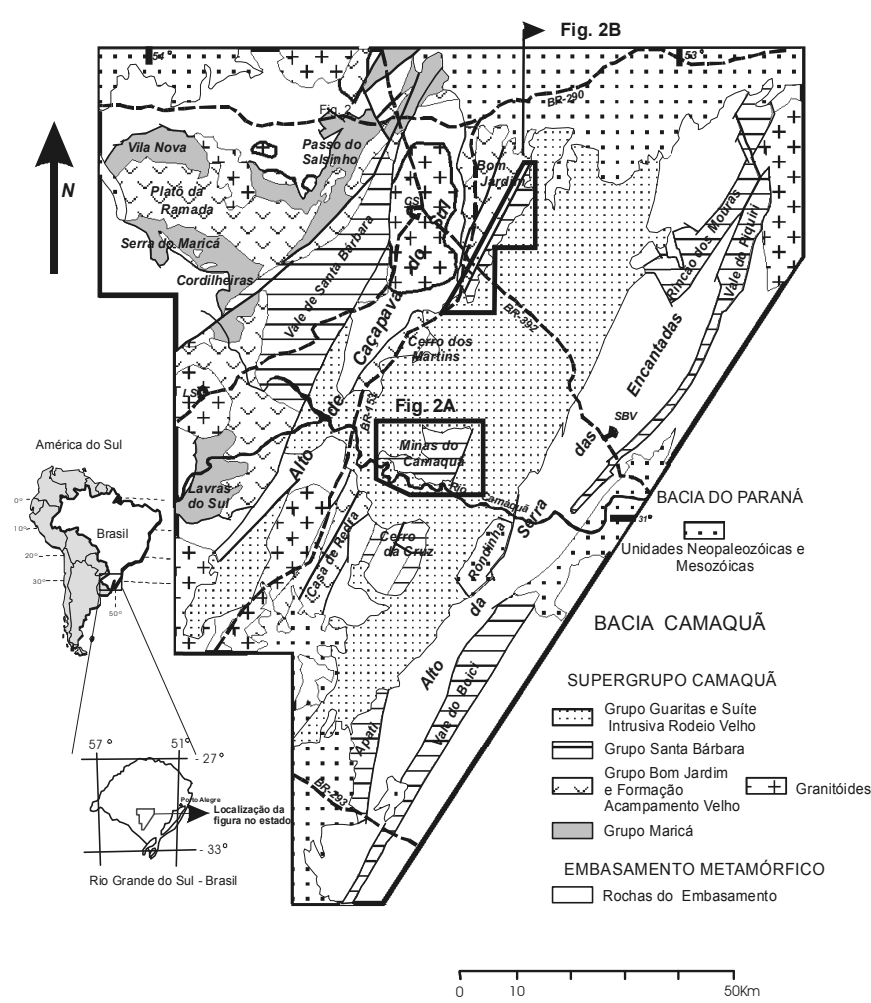

Figura 1 - Esboço geológico das unidades neoproterozóicas e eopaleozóicas do Rio Grande do Sul, com destaque para as unidades que constituem o Supergrupo Camaquã. Cidades: CSCaçapava do Sul; LS-Lavras do Sul; SBV-Santana da Boa Vista (modificada de Fragoso-Cesar et al. 2000).

regiões do Cerro da Cruz, Arroio Rondinha e Arroio Apati, além de outras menores ainda preliminarmente investigadas (Fig. 1). As rochas sedimentares que ocorrem na região das Minas do Camaquã, classicamente relacionadas à Formação Arroio dos Nobres por outros autores (e.g. Ribeiro et al. 1966, Gonzalez \& Teixeira 1980, Paim et al. 1992), são aqui consideradas como pertencentes ao redefinido Grupo Santa Bárbara (sensu Fambrini 2003). Por outro lado, os estudos estratigráficos realizados nas unidades do Grupo Santa Bárbara expostas na área de Bom Jardim mostraram a notável correspondência entre as seções levantadas nesta área e na região das Minas do Camaquã (Fig. 2) . Estima-se que a espessura do Grupo Santa Bárbara na Sub-Bacia Camaquã Central seja superior a $2000 \mathrm{~m}$.

Com relação à estratigrafia, Robertson (1966) redefiniu a "Série Camaquan" de Carvalho (1932) como Grupo Camaquã, constituído pelas formações Santa Bárbara e Guaritas. Em seguida Ribeiro et al. (1966) definiram a Formação Arroio dos Nobres como depósitos de conglomerados e arenitos mineralizados em cobre, distinguindo dos não-mineralizados relacionados à parte da Formação Santa Bárbara de Robertson (1966). Na porção oriental da área de Bom Jardim, Ribeiro et al. (1966) reconheceram a Formação Santa Bárbara em estreita faixa de afloramentos de orientação NE-SW. Posteriormente, Fambrini et al. (1996) retomaram a definição original de Formação Santa Bárbara (de Robertson 1966) para os depósitos das Minas do Camaquã, anteriormente relacionados à Formação Arroio dos Nobres de Ribeiro et al. (1966). Por outro lado, trabalhos de estratigrafia de seqüências foram realizados na Sub-
Bacia Camaquã Central por Paim et al. (1992, 2000), Paim (1994), Fragoso-Cesar et al. (2000) e Fambrini et al. (2002).

CONTEXTOGEOLÓGICOREGIONAL OGupoSantaBárbara caracteriza-se por uma sucessão aluvial-marinho-aluvial, gerada em um sistema de rifts em contexto anorogênico, possivelmente a partir de distensões na direção NW-SE (Fragoso-Cesar et al. 2001, Fambrini et al. 2001, Fambrini 2003), com a deposição de rochas siliciclásticas em ambientes aluviais, costeiros e deltaicos. O Grupo Santa Bárbara, segundo Fambrini (2003), pode ser dividido nas seguintes formações, a partir da base: Estância Santa Fé, Passo da Capela, Seival, Rincão dos Mouras e João Dias.

A Formação Estância Santa Fé (até 1.200 m), exposta somente na Sub-Bacia Camaquã Ocidental, é formada por conglomerados e arenitos gerados por sistemas de leques aluviais proximais e medianos, que passam para arenitos grossos mal selecionados de sistemas fluviais entrelaçados associados aos leques (Almeida 2001).

A Formação Passo da Capela, bem exposta nas sub-bacias Camaquã Oriental e Central, apresenta até $4.000 \mathrm{~m}$ de espessura na Sub-Bacia Camaquã Oriental (região do vale do Piquiri) e constitui-se de (i) ritmitos formados por arenitos médios a muito finos com subordinada contribuição de arenitos grossos, além de siltitos com espessura centimétrica, que representam depósitos turbidíticos de franjas externas e intermediárias de leque submarino e (ii) possantes pacotes de conglomerados e arenitos que compreendem depositados em turbiditos de franjas internas e intermediárias de leque submarino.

A Formação Seival (até $1.000 \mathrm{~m}$ ), aflorante nas sub-bacias Camaquã Ocidental e Central, constitui-se de arenitos médios a muito finos com subordinada contribuição de arenitos grossos, além de siltitos com espessura centimétrica. Compreende depósitos de: (i) baía estuarina e planície litorânea, (ii) tempestitos de costa-afora e (iii) planície de maré.

A Formação Rincão dos Mouras constitui-se de pacotes de conglomerados e arenitos conglomeráticos, comum a todas as sub-bacias da Bacia Camaquã onde ocorre o Grupo Santa Bárbara, depositados principalmente por sistemas de leques aluviais e fluviais entrelaçados. Esta unidade atinge espessura superior a 2.000 m na Sub-Bacia Camaquã Oriental.

Os depósitos aluviais da Formação Rincão dos Mouras são recobertos por depósitos marinhos da Formação João Dias, que ultrapassam $500 \mathrm{~m}$ de espessura. Os depósitos da Formação João Dias restringem-se à Sub-Bacia Camaquã Central e apresentam excelentes exposições na região das Minas do Camaquã. Esta unidade caracteriza-se pelo amplo predomínio de arenitos médios e finos contendo grãos de glauconita com claras evidências de ação de ondas de tempestade e de tempo bom, caracterizando ambiente marinho costeiro de antepraia (foreshore) e de face litorânea (shoreface).

As rochas da região das Minas do Camaquã foram objeto de estudos geocronológicos, com datações pelo método K-Ar em pelitos intercalados nos conglomerados e arenitos, fornecendo idade de $572 \pm 17 \mathrm{Ma} \mathrm{e} 535 \pm 16 \mathrm{Ma}$ (Bonhomme \& Ribeiro 1983), bem como estudos em icnofósseis que sugerem idade do Vendiano Superior (icnogênero Intrites) ao Cambriano (Netto et al. 1992), respectivamente para os depósitos basais e de topo.

O GRUPO SANTA BÁRBARA NASUB-BACIACAMAQŨ̃ CENTRAL As pesquisas realizadas nas regiões de Bom Jardim e das Minas dos Camaquã possibilitaram uma subdivisão comum para o Grupo Santa Bárbara nesta sub-bacia, constituído, a partir 


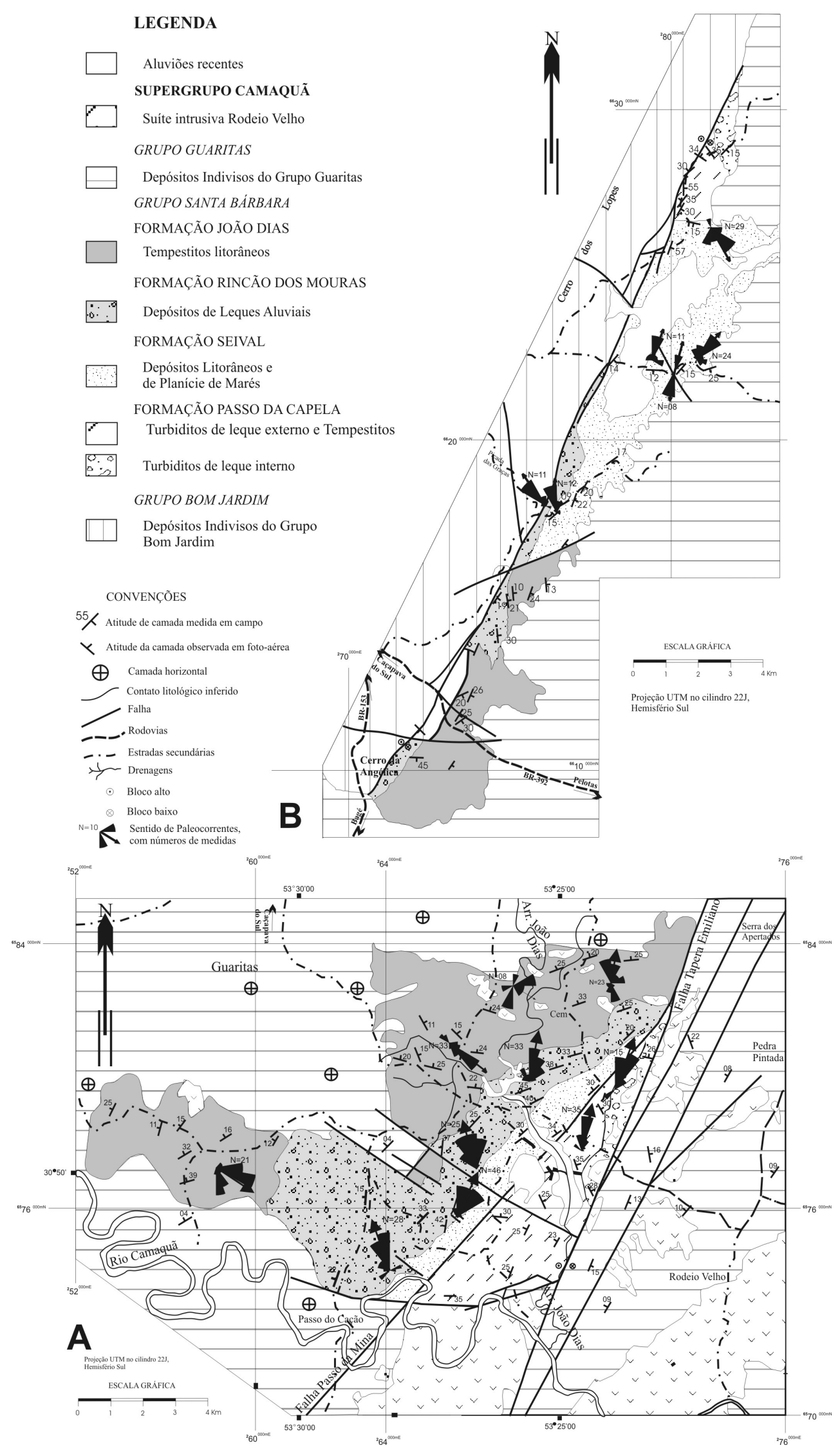

Figura 2 - A: mapa geológico do Grupo Santa Bárbara na região das Minas do Camaquã (modificado de Fambrini 1998); B: mapa geológico do Grupo Santa Bárbara na região de Bom Jardim (modificado de Janikian 2001). 
da base, pelas formações (Fig. 3) : (i) Passo da Capela, constituída de turbiditos de franjas intermediárias e externas de leque submarino, (ii) Seival, composta por depósitos gerados em planícies litorâneas, depósitos de tempestitos de costa-afora (offshore) e de planície de marés, (iii) Rincão do Mouras, formada por depósitos de sistemas aluviais e fluviais associados e (iii) João Dias, composta de depósitos litorâneos de antepraia (foreshore) e de face litorânea (shoreface) e tempestitos de face litorânea.

Os depósitos expostos na região das Minas do Camaquã acham-se truncados pela Falha do Passo da Mina, aqui definida, e pelo sistema de falhas Tapera Emiliano (Fig. 2A) que limita a leste esta sub-bacia. Na área de Bom Jardim estes depósitos estão limitados a oeste por contato tectônico, através da Falha Cerro da Angélica com o Grupo Bom Jardim (Fig. 2B).

Formação Passo da Capela A Formação Passo da Capela do Grupo Santa Bárbara na Sub-Bacia Camaquã Central é constituída por turbiditos de franjas distais de leque submarino, turbiditos de franjas proximais de leque submarino e tempestitos de costa-afora apresentando espessura aflorante superior a $500 \mathrm{~m}$ (Fig. 3) .

TURBIDITOS DE FRANJAS EXTERNAS (OUTER-FAN) DE LEQUE SUBMARINO Os depósitos basais da Formação Passo da Capela, expostos apenas na região das Minas do Camaquã da Sub-Bacia Camaquã Central (Fig. 2), caracterizam-se por depósitos gerados por correntes de turbidez em franjas externas de leque submarino.

Estes depósitos turbidíticos (Fig. Ver fambrini@camaqu. cjb.net) compõem-se de camadas tabulares decimétricas (30-70 $\mathrm{cm})$, excepcionalmente métricas (1-1,5 m), com grande persistência lateral, constituindo ritmitos psamo-pelíticos que possuem gradação normal das seguintes fácies, a partir da base: (i) arenitos médios a finos com fragmentos esparsos pela matriz (grânulos e pequenos seixos), por vezes de granulometria grossa, maciços a grosseiramente laminados; (ii) arenitos médios a finos maciços dispostos em camadas amalgamadas; (iii) arenitos médios a finos com laminação cruzada cavalgante de corrente (climbing ripples); (iv) siltitos deformados em camadas lenticulares decimétricas e (v) siltitos e argilitos laminados de espessura centimétrica de ocorrência subordinada.

As associações das fácies acima descritas em conjunto com a gradação normal, a tabularidade eminente das camadas e as características intrínsecas de transporte dos depósitos permitem interpretá-los como originados por correntes de turbidez abaixo da ação de ondas (turbiditos marinhos de baixa densidade) compondo uma sucessão retrogradacional com predomínio de fácies finas. Estes depósitos foram classificados como turbiditos clássicos finos, segundo critérios de Walker (1992).

\section{TURBIDITOS DE FRANJAS INTERNAS (INNER-FAN) E DE} FRANJAS EXTERNAS (OUTER-FAN) DE LEQUE SUBMARINO Estes depósitos sobrepõem-se aos turbiditos clássicos finos por contato erosivo. Na região de Bom Jardim (Fig. 3B), onde são mais espessos, com cerca de $150 \mathrm{~m}$, compreendem arenitos conglomeráticos e conglomerados polimíticos, sustentados pelos clastos, que variam de seixo a calhau (de até $15 \mathrm{~cm}$ de diâmetro), subangulosos a subarredondados. Os conglomerados mostramse predominantemente maciços na área de Bom Jardim, mas também podem ser bem estratificados, como na área das Minas do Camaquã onde atingem espessuras métricas (até 1,50 m), encontrando-se dispostos em camadas de geometria tabular. Em geral,

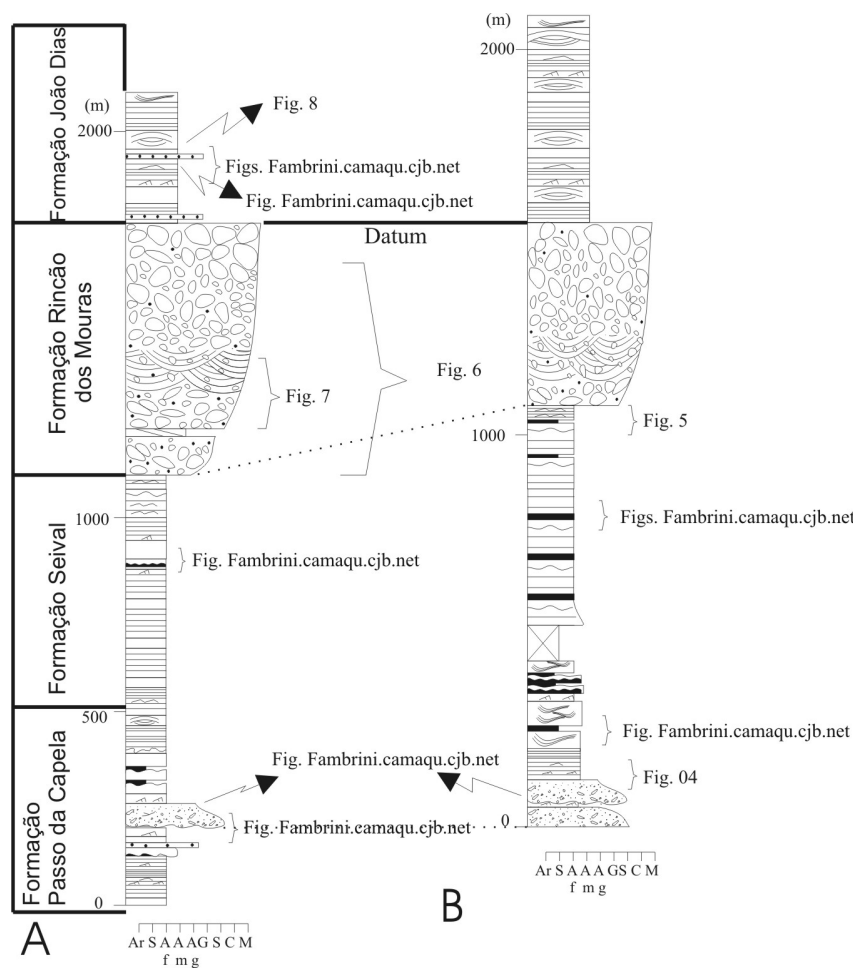

Figura 3 - Comparação entre as seções colunares do Grupo Santa Bárbara aflorantes nas regiões das Minas do Camaquã (A) e de Bom Jardim (B).

estes conglomerados expõem-se na forma de lajeados que suportam o relevo onde ocorrem. Por vezes intercalam-se camadas tabulares centimétricas a decimétricas de arenitos grossos com grânulos e seixos esparsos, com estratificação horizontal, e lentes de conglomerados polimíticos sustentados pelo arcabouço na forma de bolsões de clastos, que exibem contato clasto-a-clasto e, mais raramente, imbricação dos mesmos (e.g. Minas do Camaquã). As associações de fácies observadas na porção basal desta segunda unidade permitiu interpretar a ocorrência de processos de fluxos de gravidade e correntes de turbidez de alta densidade durante a sedimentação, o que evidencia variações do nível de base relativo possivelmente relacionadas às atividades tectônicas da bacia, gerados em ambientes proximais do leque submarino.

Em direção ao topo desta segunda unidade, os depósitos conglomeráticos e areno-conglomeráticos de franjas internas transicionam para camadas de granulometrias mais finas, de geometrias tabulares e espessuras centimétricas a decimétricas, constituídas por (i) arenitos grossos micáceos com estratificação horizontal ou mesmo maciços, por vezes com grânulos concentrados na base das camadas, (ii) arenitos finos e pelitos com laminação plano-paralela (Fig. 4). A granodecrescência dos ciclos, a tabularidade das camadas e as características de transporte sedimentar acima interpretadas indicam deposição por fluxos de gravidade alternados por correntes de turbidez de baixa densidade no sentido de Lowe (1982), abaixo da zona de ação de ondas de tempestades, em porções distais de leque submarino.

Análise de Proveniência Na região das Minas do Camaquã os conglomerados possuem clastos de leucogranitos róseos médios, riolitos, xistos, milonitos, quartzo branco leitoso, quartzo ví- 
treo, feldspato e quartzitos (Fig. ver fambrini@camaqu.cjb.net). $\mathrm{Na}$ área de Bom Jardim, a análise estatística do arcabouço dos conglomerados indica uma fonte predominantemente de rochas do embasamento (filito, metabasito, xisto e quartzito), rochas vulcânicas de composição ácida, subordinadamente intermediária, e fragmentos de arenitos finos, quartzo de veio e granito de textura fina (Fig.verfambrini@camaqu.cjb.net).

A grande contribuição de rochas do embasamento nestes pacotes conglomeráticos basais permitem inferir um rearranjo tectônico da bacia, com soerguimento do embasamento e, assim, variação do nível de base relativo e do aporte sedimentar, que resultou numa superfície erosiva sobre os depósitos da unidade de turbiditos finos da porção basal da Formação Passo da Capela.

TEMPESTITOS DE COSTA-AFORA (OFFSHORE) A Anidade de topo da Formação Passo da Capela, na Sub-Bacia Camaquã Central, constitui-se por ritmitos com intercalações de camadas, centimétricas a decimétricas, de arenitos finos a médios, micáceos, e de siltitos arenosos, com ocorrência subordinada de argilitos. A forma rítmica de distribuição das frações granulométricas é típica desta sucessão. A espessura estimada atinge cerca de $350 \mathrm{~m}$.

Na região de Bom Jardim (Figs. ver fambrini@camaqu.cjb.net) estes depósitos destacam-se em ciclos decimétricos de arenitos finos com laminação horizontal e heterolítica, por vezes com laminações cruzadas cavalgantes, intercalados com camadas de igual espessura de arenitos médios, excepcionalmente grossos, com estratificação horizontal, ou maciços. A geometria do conjunto é predominantemente tabular. Intercalam-se também camadas de arenitos médios a finos com estratificações cruzadas tabulares de baixo ângulo e do tipo hummocky, de geometrias lenticulares. Em seção delgada foram observados minerais de glauconita, indicativos de ambiente marinho.

As fácies com estratificações cruzadas do tipo hummocky e swalley apontam ação de ondas de tempestades, sendo registrados períodos de atenuação ou calmaria, com a deposição de fácies heterolíticas que indicam episódios de deposição em águas mais profundas, abaixo do nível de ação das ondas de tempo bom, em zona de transição de costa-afora (offshore transition).

Na região das Minas do Camaquã esta porção inferior distingue-se pela tabularidade dos estratos, granodecrescência ascendente, alternância de camadas de arenitos finos de topo e base ondulados com níveis centimétricos de siltitos, com estruturas como laminação horizontal, laminação cruzada truncada por migração de ondas (mini-hummocky no sentido de Dott \& Bourgeois 1982), quando o comprimento de onda é inferior a $1 \mathrm{~m}$, laminações cruzadas cavalgantes e, no topo das camadas arenosas, marcas onduladas simétricas com comprimento de onda variando de 1 a 6 $\mathrm{cm}$, indicativas de oscilação.

As associações de fácies observadas nesta unidade são interpretadas como produtos de eventos esporádicos de transporte e acumulação de material arenoso sob a ação combinada de fluxo oscilatório e unidirecional (no sentido de Cheel \& Leckie 1992 e Myrow \& Southard 1996), gerado por ondas de tempestades em ambiente marinho raso. Estes tempestitos de costa-afora (offshore transition) gradacionam para depósitos de face litorânea (shoreface) em ambiente marinho raso (Fambrini et al. 1996, Fambrini 1998, Janikian 2001).

Análise de Paleocorrentes Nos depósitos da área de Bom Jardim foram obtidas 29 medidas de paleofluxos a partir de marcas onduladas assimétricas e, subordinadamente, de laminações cru-

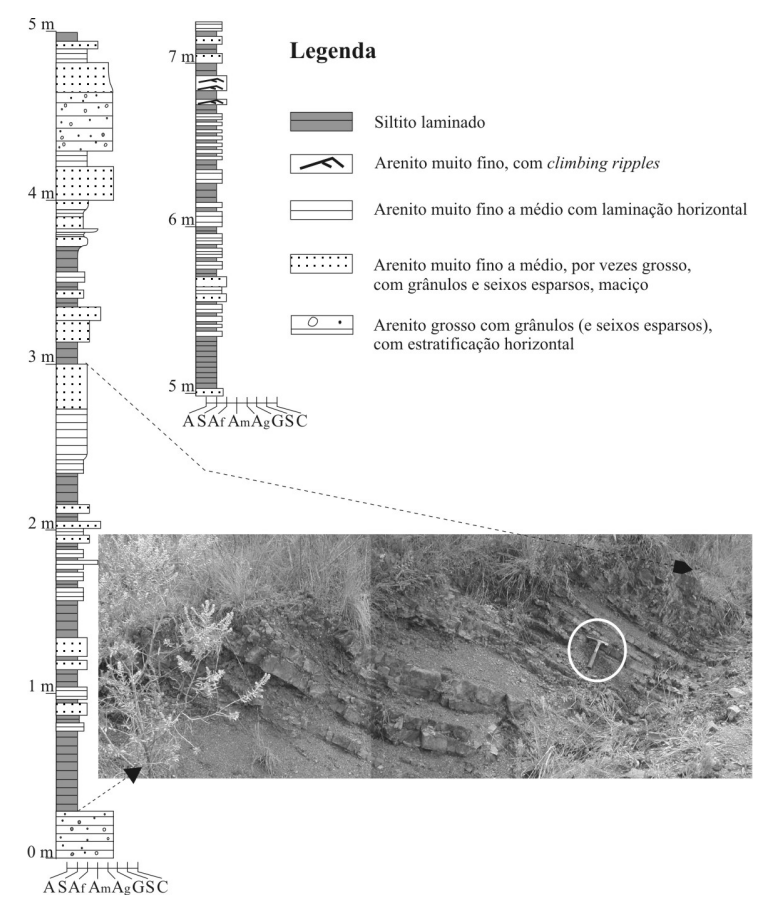

Figura 4 - Turbiditos de franjas externas de leque submarino da Formação Passo da Capela na região de Bom Jardim (modificada de Janikian 2001).

zadas cavalgantes, bem como de estratificações cruzadas tabulares (Janikian 2001). Estas medidas de paleocorrentes foram interpretadas como correntes de deriva litorânea (longshore currents), com paleofluxo médio para SE (Fig. 2B).

Formação Seival AFormação Seival é constituída por depósitos litorâneos e de planície de marés, e sua espessura aflorante é da ordem de $600 \mathrm{~m}$ (Fig. 3).

DEPÓSITOS LITORÂNEOS E DE PLANÍCIE DE MARÉS Os depósitos litorâneos na região das Minas do Camquã compreendem pacotes tabulares de espessura variável (decimétricos a métricos, até $2 \mathrm{~m}$ ) de ritmitos psamo-pelíticos (Fig. ver fambrini@ camaqu.cjb.net) formados internamente pela alternância brusca de três fácies: (i) arenitos médios a finos, maciços, comumente de base erosiva, com (ii) arenitos médios a finos, micáceos, com laminação plano-paralela e lineação primária de fluxo (parting lineation), com (iii) delgada película de argila na interface das camadas arenosas apresentando gretas de contração. Estas fácies geralmente postam-se na base dos ciclos. Também são observadas camadas tabulares decimétricas de arenitos médios com estratificações cruzadas tabulares de baixo-ângulo e camadas milimétricas a centimétricas de arenitos com laminação cruzada cavalgante e ondulada. Estes depósitos litorâneos apresentam espessura aproximada de $500 \mathrm{~m}$.

Os depósitos de planície de marés apresentam pacotes tabulares de espessura variável de (i) arenitos com laminação cruzada cavalgante, marcas onduladas por corrente associadas (current ripples) e laminação ondulada (wavy bedding), por vezes realçada por lentes de argilitos em meio às camadas areníticas constituindo laminação flaser, associados a siltitos com laminação plano-para- 
lela, arenitos laminados e arenitos maciços, (ii) arenitos médios com estratificações cruzadas tabulares de médio porte e baixo ângulo $\left(\theta=5^{\circ}-8^{\circ}\right)$ de caráter bimodal (sentidos opostos de mergulho dos foresets das estratificações), geometria tabular, bem selecionados por estrato, formando sucessões granodecrescentes para o topo das camadas; freqüentemente ocorrem filmes de argila (drapes). As camadas heterolíticas com estruturas como flaser, wavy e arenitos lenticulares (linsen), bem como estratificações cruzadas de baixo ângulo com sentidos opostos de mergulho dos estratos, levaram Fambrini (1998) a interpretar um ambiente transicional de lâmina d'água rasa de ambiente de planície de marés para a região das Minas do Camaquã, conforme critérios de De Raaf et al. (1977). Recentemente, identificou-se estruturas tidal bundles nestes depósitos, reforçando esta interpretação.

Esta interpretação foi seguida por Janikian (2001) para depósitos análogos na área de Bom Jardim, onde identificou estruturas fundamentais para tal. Estas estruturas são compostas por camadas lenticulares de arenitos grossos a finos com espessuras centimétricas a decimétricas, com estratificação cruzada tangencial na base e com abundantes lâminas argilosas (por vezes recurvadas) nos estratos frontais (Fig. ver fambrini@camaqu.cjb.net), constituindo tidal bundles, com superfícies de reativação no topo. Também foram observadas estruturas com geometrias lenticulares, de largura métrica e altura decimétrica, preenchidas por siltitos laminados (Fig. ver fambrini@camaqu.cjb.net), interpretadas como pequenos canais de intermaré (tidal creeks).

De maneira geral, os depósitos de planície de marés, na região de Bom Jardim, constituem-se por camadas decimétricas a métricas, tabulares, formadas por intercalações de níveis centimétricos a milimétricos de arenitos muito finos a médios, que freqüentemente apresentam-se maciços, laminados e com laminação cruzada cavalgante, bem como camadas decimétricas heterolíticas.

O topo da Formação Seival na região de Bom Jardim é composto por intercalações centimétricas de arenitos muito finos laminados com marcas onduladas no topo e de siltito laminado, que progradam para camadas com níveis de arenitos muito grossos com estratificação plano-paralela com diversas superfícies com marcas onduladas assimétricas e gretas de contração (base da Fig. 5) .

Análise de Paleocorrentes Nos depósitos de marés da área de Bom Jardim (Fig. 3B) foram coletadas 19 medidas a partir de marcas onduladas e, subordinadamente, laminações cruzadas cavalgantes, interpretadas como originadas como correntes de maré. Apesar do pequeno número de medidas, a bipolaridade e bimodalidade das correntes foram observadas.

Em depósitos de barras de submaré, que registram a corrente de maré dominante, 24 medidas de paleofluxo foram obtidas em estratificações cruzadas de maré, indicando sentido de paleocorrentes para NE (Fig. 3B). A presença de um único sentido de migração de correntes nestes depósitos advém do mecanismo gerador da barra, que se move apenas durante a corrente dominante (diária e bidiária), sendo erodida pela corrente subordinada (superfícies de reativação) e registrando os períodos de estagnação como camadas de siltitos.

Formação Rincão dos Mouras A Formação Rincão dos Mouras compreende espessos depósitos rudáceos $(>500 \mathrm{~m}$ na região das Minas do Camaquã) com padrão granocrescente para o topo de conglomerados, interpretados como depósitos de leques aluviais. Subordinadamente ocorrem arenitos conglomeráticos e arenitos com estratificações cruzadas acanaladas, possivelmente relacio-

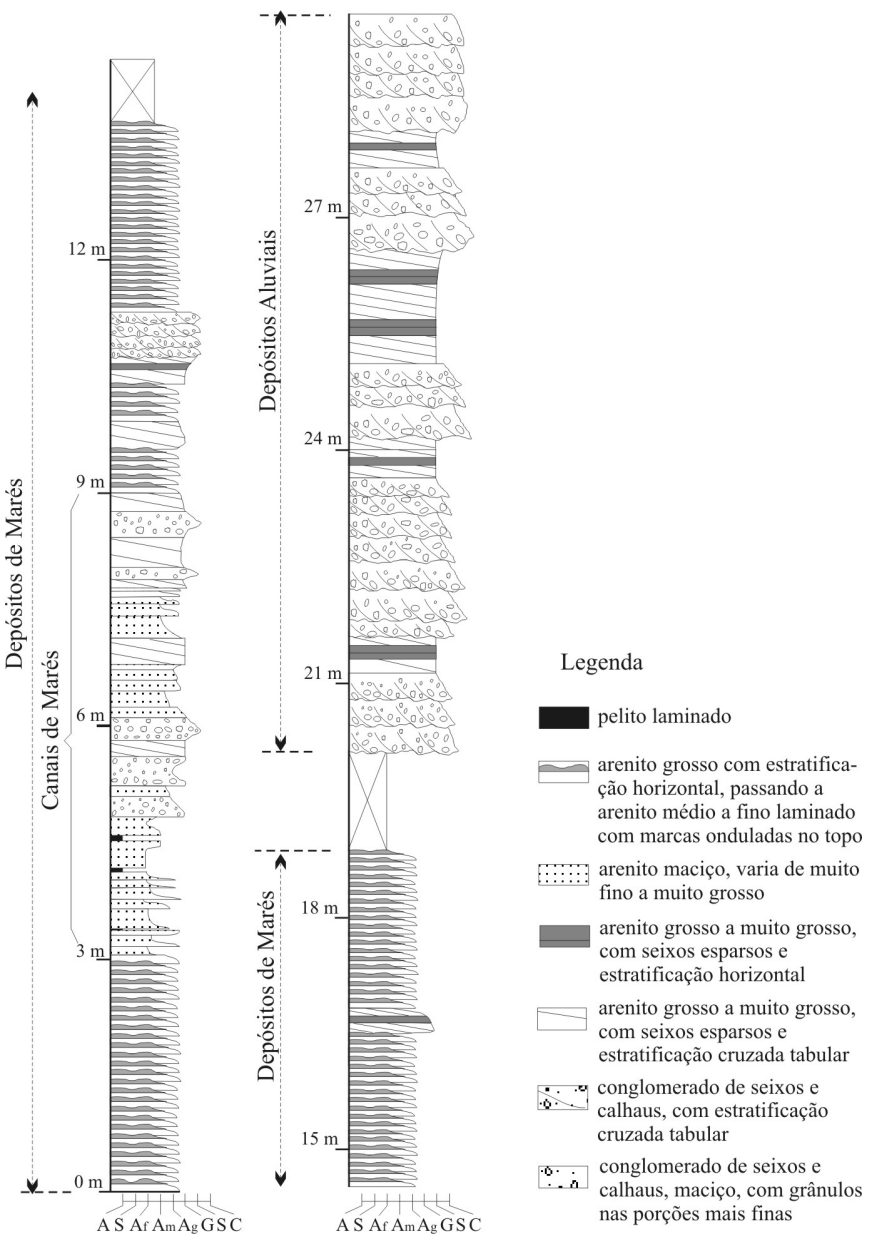

Figura 5 - Seção de detalhe da porção de topo dos depósitos de planície de maré da Formação Seival, na região de Bom Jardim, passando para os depósitos aluviais da Formação Rincão dos Mouras (modificada de Janikian 2001).

nados à implantação de sistemas fluviais entrelaçados. Estes depósitos apresentam excelentes exposições na área das Minas do Camaquã (e.g. cava a céu aberto da extinta Companhia Brasileira do Cobre (CBC), além de exposições naturais), bem como na porção sudoeste da área de Bom Jardim.

DEPÓSITOS DE LEQUES ALUVIAIS Na região das Minas do Camaquã, os depósitos da Formação Rincão dos Mouras consistem de conglomerados métricos separados por camadas decimétricas de arenitos conglomeráticos com estratificações plano-paralelas e cruzadas dos tipos acanalado e tabular.

A porção inferior (Fig. 6) compreende camadas de geometria tabular e espessuras decimétricas de conglomerados organizados, normalmente bem estratificados, polimíticos sustentados por matriz, com clastos da granulometria seixo e, subordinadamente, calhau de até $15 \mathrm{~cm}$, predominantemente subangulosos, sendo os clastos de calhaus geralmente melhor arredondados. Estes conglomerados gradam para ou intercalam-se com arenitos conglomeráticos pobremente organizados em camadas de até 1,5 $\mathrm{m}$, arenitos grossos a médios, por vezes finos, bem estratificados, com acamadamentos plano-paralelos e estratificações cruzadas dos tipos tabular e acanalado. No topo das camadas, encerrando 
um ciclo, pode haver película de siltitos exibindo gretas de contração. Comumente intercalam-se nestas fácies conglomerados maciços de geometria lenticular de espessura variando de $50 \mathrm{~cm}$ a 1 $\mathrm{m}$, alternados em contato brusco, sobretudo na base dos ciclos. A matriz em geral compõe-se de arenito médio a grosso, mal selecionado, com grânulos. Como estruturas sedimentares presentes destacam-se estratificação plano-paralela, estratificações cruzadas acanaladas de baixo ângulo e médio porte e tênue imbricação de clastos.

A porção superior (Fig. 7) é composta de conglomerados polimíticos pouco a bem organizados, sustentados pelo arcabouço (50-60\% do arcabouço) formado de clastos de seixo a matacão (até $120 \mathrm{~cm}$ de diâmetro), angulosos a arredondados, dispostos em camadas de geometria tabular de espessuras decimétricas (30-70 $\mathrm{cm}$ ), por vezes métricas, de extensão lateral grande, separados por níveis de arenitos grossos conglomeráticos. A matriz é composta por arenito médio a grosso a muito grosso com grânulos. Internamente, os pacotes podem exibir estratificações cruzadas acanaladas de baixo ângulo e médio porte, gradação normal e estratificação plano-paralela, e imbricação de clastos ocasional.

Na área de Bom Jardim, a sucessão de leques aluviais compõese de intercalações de conglomerados sustentados pelo arcabouço com matriz arenosa e arenitos conglomeráticos portando estratificação plano-paralela que gradam, em direção ao topo, para conglomerados sustentados pela matriz arenosa com estratificação cruzada tabular de médio e pequeno porte e plano-paralela (Fig. 5).

Estes depósitos foram interpretados como originados pela ação de fluxos inicialmente confinados (porção inferior) da carga sedimentar que, ao atingirem o corpo marinho da Formação Seival, sofreram desaceleração e desconfinamento, acarretando a formação de depósitos de enchentes em lençol (sheet-floods sensu Blair \& McPherson 1994 e Blair 1999). A sucessão vertical de fácies seguidamente mais grossas para o topo da coluna, chegando a conglomerados com matacões (Fig. 7), testemunha o caráter progradacional desta associação, culminando com a substituição gradual de fácies subaquáticas litorâneas da Formação Seival por aquelas desenvolvidas em ambiente subaéreo de leques aluviais dominados por processos de enchentes em lençol, caracterizando assim ambiente de leques aluviais (no sentido de Steel et al. 1977). No topo desta sucessão, bem expostas nas Minas do Camaquã, aparecem camadas métricas (1-1,5 m) de arenitos conglomeráticos com abundantes estratificações cruzadas acanaladas de médio e pequeno porte interpretadas como a porção distal dos leques e sistemas fluviais entrelaçados associados. Estes depósitos são bruscamente recobertos por arenitos marinhos da Formação João Dias, indicando tratar-se de um trato transgressivo, como veremos adiante.

Análise de Paleocorrentes As medidas de paleocorrentes dos depósitos de leques aluviais refletem consistentemente paleotransporte transversal à sub-bacia para NNW revelando áreas fontes a S e, principalmente, a SE (Fig. 2) . A distribuição de fácies enfatiza as medidas de paleocorrentes obtidas.

Análise de Proveniência Na região das Minas do Camaquã os conglomerados dos depósitos de leques aluviais apresentam clastos de diversas origens (Fambrini 1998, Fambrini et al. 1998). $\mathrm{Na}$ base dos conglomerados predominam fragmentos de leucogranitos róseos, quartzo, quartzitos róseos a esverdeados, leucogranitos foliados, xistos, arenitos finos achocolatados, vulcânicas ácidas, andesitos, conglomerados e milonitos (Fig. ver fambrini@camaqu.cjb.net). Para o topo há o progressivo predomínio de milonitos destes granitóides, granitos porfiríticos, granitos com turmalina e greizenizados, arenitos e conglomerados das unidades inferiores e mármores, concomitante ao aumento na granulometria (Fig. ver fambrini@camaqu.cjb.net). Petrograficamente, estes depósitos possuem derivação de áreas fontes granito-gnáissicas deformadas e metamórficas, de corpos graníticos intrusivos e de coberturas vulcano-sedimentares situadas a sul (Fambrini 1998, Fambrini et al. 1998).

Na região de Bom Jardim, a análise de proveniência mostrou o predomínio dos termos sedimentares e vulcânicos nestes depósitos, com uma diminuição da quantidade de clastos do embasamento e aumento de fonte granítica em direção ao topo desta unidade (Figs.verfambrini@camaqu.cjb.net).

Formação João Dias Aunidade de topo do Grupo Santa Bárbara na Sub-Bacia Camaquã Central constitui-se de espessos depósitos $(>500 \mathrm{~m})$ de arenitos marinhos costeiros dominados por ondas, interpretados como decorrentes de um evento de inundação por transgressão marinha sobre os registros de leques aluviais. Estes depósitos marinhos foram reconhecidos apenas na SubBacia Camaquã Central, tanto na região das Minas do Camaquã quanto na área de Bom Jardim, e definidos como Formação João Dias por Fambrini (1998), que identificou fácies de tempestitos em seus depósitos. Anteriormente interpretada como flúvio-deltaica (Faccini et al. 1987, Paim 1994), seu ambiente deposicional é aqui revisado.

Esta unidade caracteriza-se pelo predomínio de arenitos médios bem selecionados, apesar de localmente ocorrerem arenitos finos e camadas pouco espessas de conglomerados finos (níveis com seixos residuais). São os depósitos de maior expressão areal na região das Minas do Camaquã, limitando-se por contato brusco com a Formação Rincão dos Mouras, sotoposta, e por discordância angular e erosiva com os arenitos e arenitos conglomeráticos do Grupo Guaritas, sobrepostos.

A Formação João Dias pode ser dividida em duas porções: inferior, com depósitos de antepraia e de face litorânea superior e superior, com tempestitos de face litorânea.

DEPÓSITOS DE ANTEPRAIA (FORESHORE) E FACE LITORÂNEA SUPERIOR (UPPER SHOREFACE) Na região das Minas do Camaquã a porção inferior da Formação João Dias compreende camadas centimétricas (mais abundantes) e decimétricas de arenitos micáceos médios, por vezes finos, de coloração róseoavermelhada, de geometria tabular com topo e base ondulados (Fig. ver fambrini@camaqu.cjb.net). Internamente, as camadas centimétricas de arenitos possuem estratificações cruzadas de baixo ângulo dos tipos tangencial e/ou tabular, predominantemente de pequeno porte, estratificação e laminação plano-paralela, freqüentemente associadas a lineações primárias de corrente, marcas onduladas, geralmente assimétricas no topo das camadas, e algumas vezes com laminações cruzadas cavalgantes associadas. Nas camadas decimétricas aparecem estratificação inclinada de baixo-ângulo (swash) (Fig. ver fambrini@camaqu.cjb.net), freqüentes discordâncias e megaondulações (megaripples). Localmente, na base logo acima do contato com a Formação Rincão dos Mouras, ocorrem níveis decimétricos $(10-15 \mathrm{~cm})$ de seixos residuais (lags).

Estes depósitos da porção inferior da Formação João Dias são interpretados como ambiente de antepraia (foreshore) e de face litorânea superior (upper shoreface) ou zona de surfe (surf zone). 
As evidências de ambiente de antepraia (foreshore) são as estratificações cruzadas swash, que refletem processos de espraiamento na linha de costa, e a estratificação plano-paralela, muitas vezes apresentando lineação primária de corrente (parting lineation), indicativa de regime de fluxo superior. Ambientes de face litorânea superior (upper shoreface) ou zona de surfe (surf zone) estão registrados principalmente por megaondulações (megaripples), que são ondas de tempo bom (fairweather), e níveis de seixos associados a estratificações cruzadas e representantes de depósitos residuais (lags) que teriam sido depositados por retrabalhamento de material retirado da antepraia por espraiamento das ondas.

TEMPESTITOS DE FACE LITORÂNEA (SHOREFACE) A por-
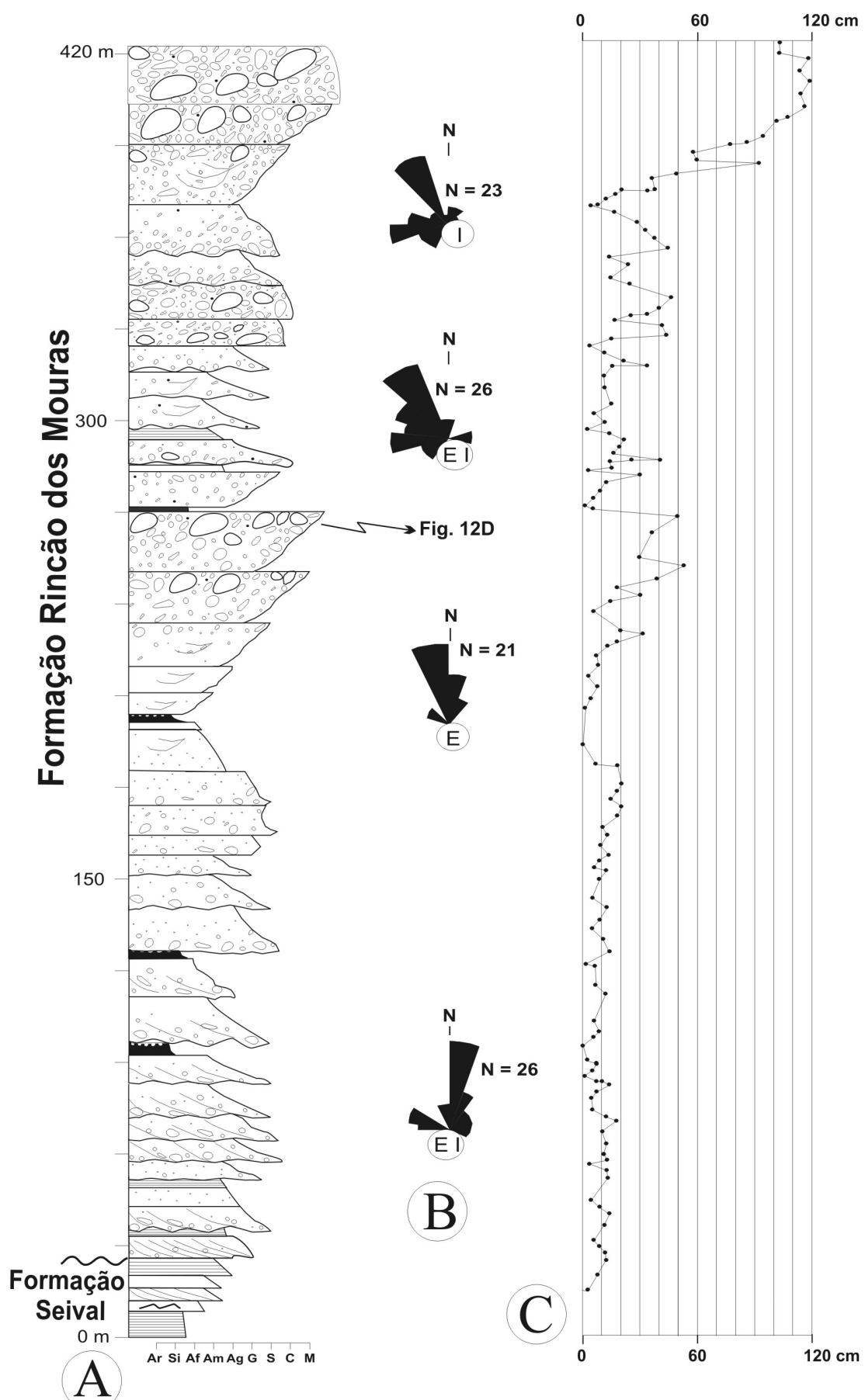

Legenda
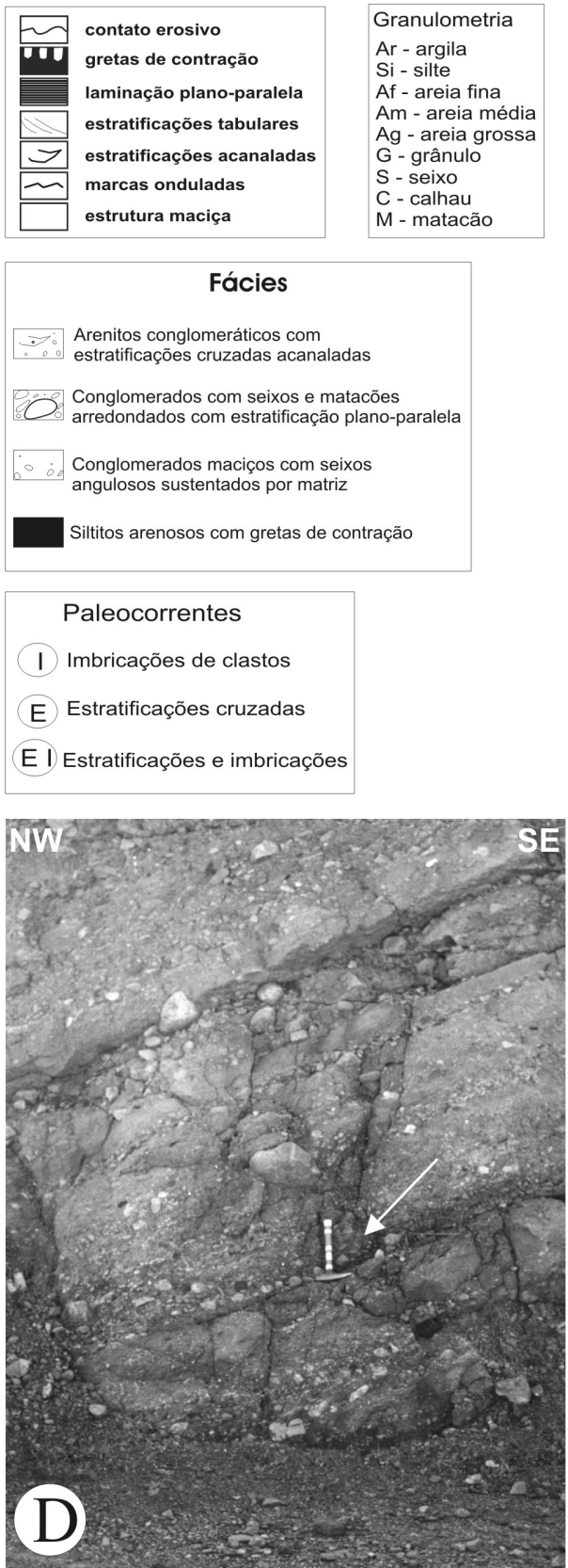

Figura 6 - A: Seção colunar de detalhe de parte do topo da Formação Seival e grande parte da Formação Rincão dos Mouras do Grupo Santa Bárbara levantada na cava a céu aberto da Mina Uruguai (CBC), Minas do Camaquã, B: paleocorrentes obtidas nos níveis compatíveis, $\boldsymbol{C}$ : gráfico com o tamanho máximo dos clastos, D: foto de detalhe dos conglomerados estratificados. Seta indica escala. Modificada de Fambrini et al. (1998). 


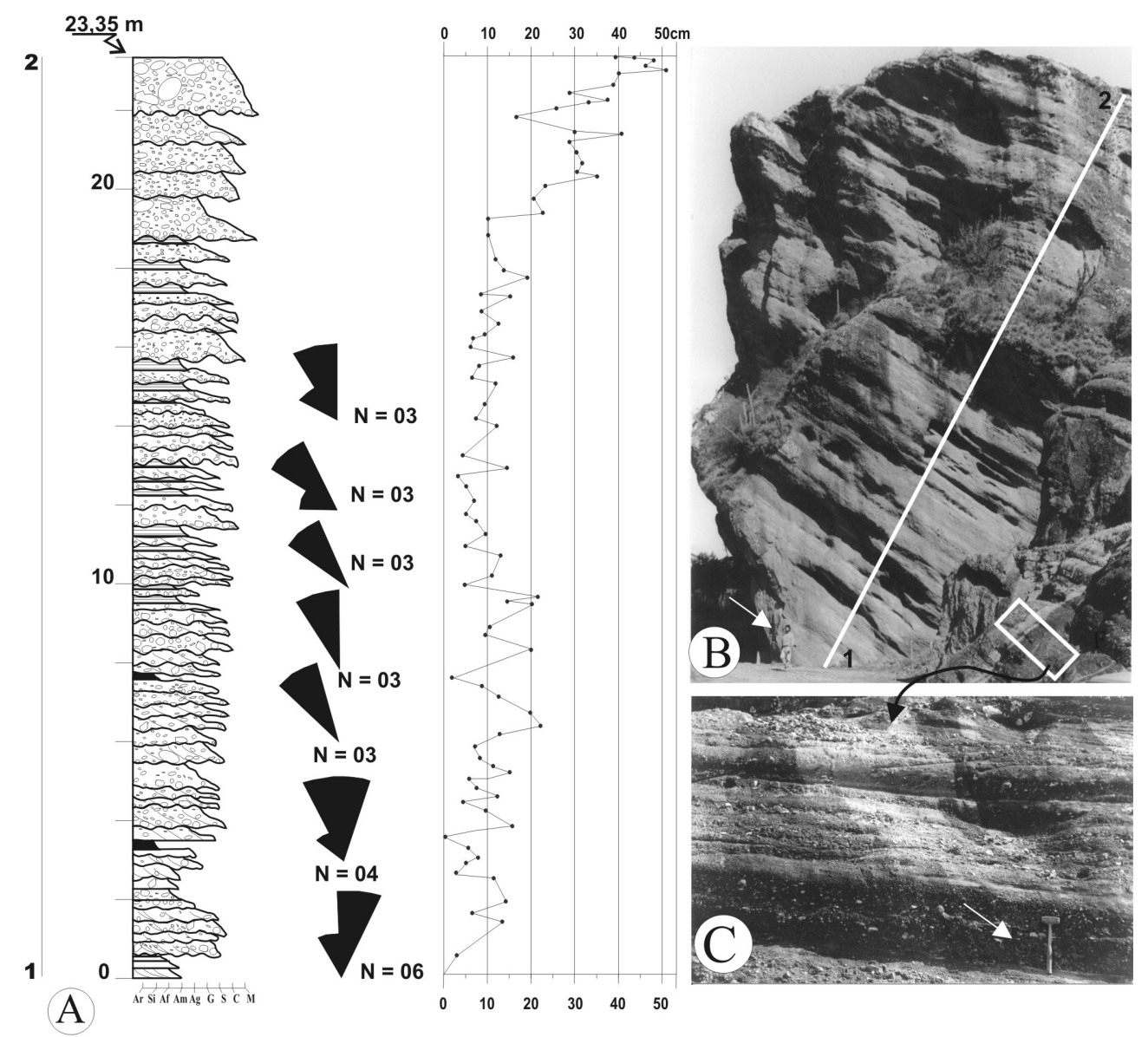

Figura 7 - Leques aluviais da Formação Rincão dos Mouras na região das Minas do Camaquã. A: Seção de detalhe da porção superior dos depósitos de leques aluviais, com paleocorrentes e gráfico com o tamanho máximo dos clastos medidas em cada camada investigada; B: foto da seção levantada (barra branca); C: foto de detalhe dos depósitos aluviais. Modificada de Fambrini (1998). Fácies vide Fig. 6. Setas brancas indicam escalas utilizadas.

ção superior da Formação João Dias é constituída por arenitos micáceos finos a médios, de coloração róseo-avermelhada, com estratificação e laminação cruzadas de baixo ângulo tangencial e/ ou tabular, de pequeno a médio porte, estratificações cruzadas tipo hummocky no sentido de Duke et al. (1991) (Fig. 8), estratificação cruzada swaley e marcas onduladas assimétricas no topo das camadas. Esta porção caracteriza a face litorânea intermediária (medium shoreface) ou zona de arrebentação (breacker zone), onde ocorre o predomínio de ondas de tempo bom. Mas durante as tempestades (storm weather), algumas estruturas são preservadas nesta região, no fim de um ciclo de tempestade. As estratificações cruzadas swaley e estratificações cruzadas hummocky representam esses eventos de tempo ruim. Em seções delgadas ocorre abundância de glauconita, típica de depósitos marinhos devido às condições ambientais, de temperatura, de profundidade e também pela sua composição (Van Houten \& Purucker 1985, Odin 1988, Chafetz \& Reid 2000).

As fácies da porção superior dos depósitos marinhos costeiros sugerem ambiente costeiro dominado por ondas de tempo bom com a ocorrência eventual de ondas de tempestades, exemplificadas pelas estratificações cruzadas swaley e hummocky, que representam esses eventos de tempo ruim.

Portanto, esta unidade representa um sistema deposicional marinho costeiro, dominado por ondas de tempo bom e afetado por eventos de tempestade.

ANÁLISE DE PALEOCORRENTES Aanálise de paleocorrentes de ambientes marinhos rasos e costeiros dominados por ondas é de difícil interpretação devido à variedade de processos atuantes nesse tipo de ambiente. As principais estruturas indicativas de paleofluxo encontradas foram estratificações cruzadas tipo swaley e estratificações cruzadas por migração de dunas subaquáticas (tabulares e tangenciais). Adicionalmente efetuaram-se medidas em cristas de marcas onduladas assimétricas dos tipos retilíneo, sinuoso e linguóide (conforme classificação de Collinson \& Thompson 1989) e de estratificações cruzadas tabulares de pequeno e médio portes.

As estratificações cruzadas swaley são geradas por processos de fluxo oscilatório e fluxo combinado (oscilatório mais unidirecional) no sentido de Cheel \& Leckie (1992), sendo que, na segunda hipótese, a componente de fluxo unidirecional pode ser medida através da assimetria da estrutura (Yagishita et al. 1992). As estratificações tipo swaley são o resultado do preenchimento concordante de escavações circulares a elípticas geradas por oscilação em eventos de tempestades, e a componente unidirecional normalmente está associada a correntes de retorno que atuam 

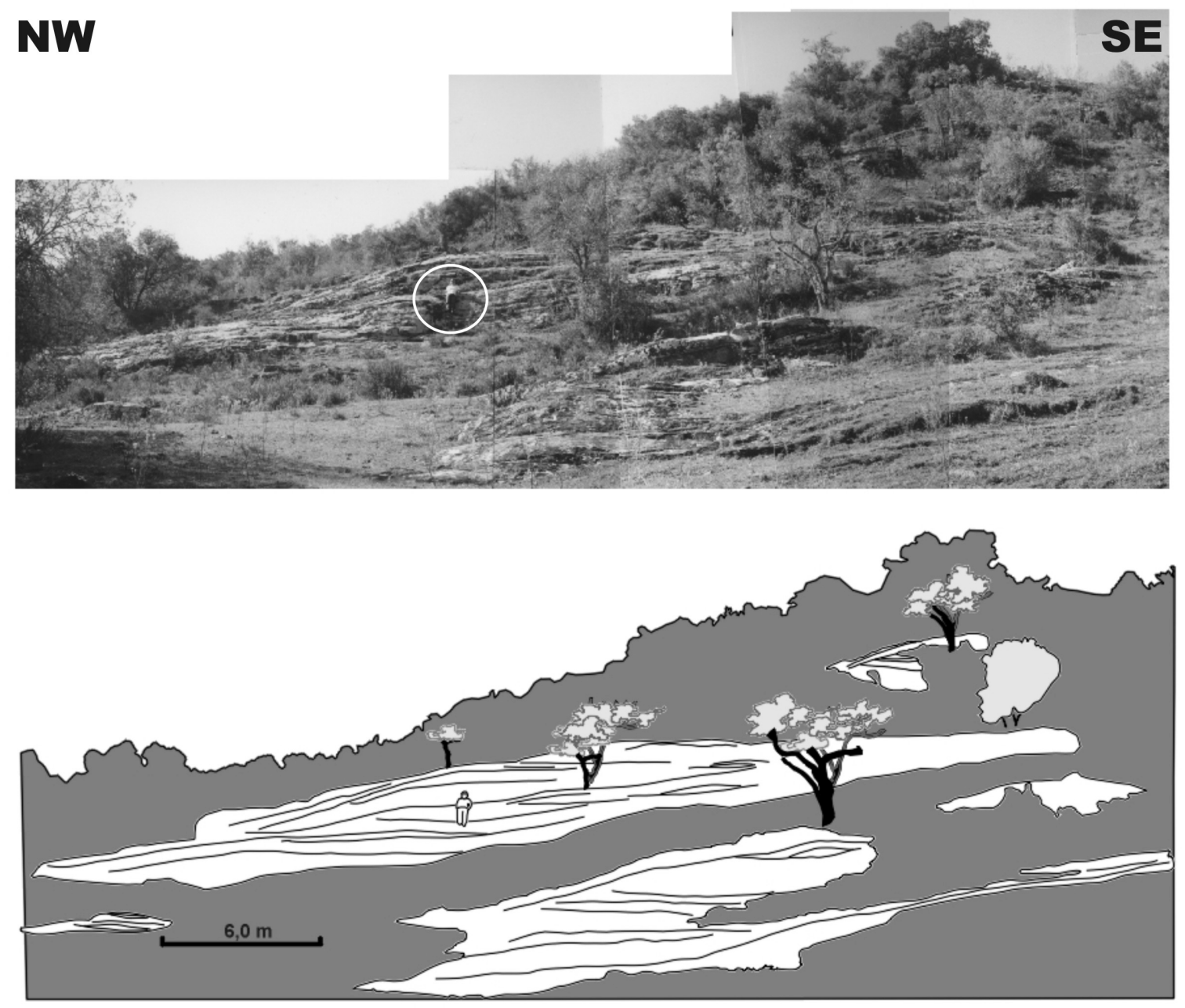

Figura 8 - Depósitos de arenitos finos com estratificações cruzadas do tipo hummocky. Unidade de Tempestitos Litorâneos da Formação João Dias, na região das Minas do Camaquã.

durante a atenuação da tempestade (Allen \& Underhill 1989). Dessa forma, os planos de estratificações possuem grande dispersão de mergulhos e, segundo Yagishita et al. (1992), a paleocorrente unidirecional fica registrada como o vetor médio do flanco de maior mergulho da estratificação.

Nos depósitos de tempestitos de face litorânea foram analisadas paleocorrentes de estratificações cruzadas swaley através da medição de diversos planos, sem o reconhecimento preliminar dos planos de maior mergulho devido à possibilidade de seu mascaramento pelo basculamento tectônico. Assim, após a medição de vários planos, realizou-se a correção do basculamento e só então reconheceu-se a assimetria da forma e o sentido dos planos de maior mergulho. A Fig. 2A representa planos de estratificações cruzadas swaley, mostrando forte assimetria com elongamento da direção N-S, e paleocorrentes para norte.

Outra estrutura indicativa de paleocorrentes na área compreende estratificações cruzadas geradas por migração de dunas subaquáticas. Estas resultam de correntes unidirecionais e, em ambientes costeiros dominados por ondas, são interpretadas como produto de correntes costeiras, principalmente de deriva litorânea (longshore currents) (Walker \& Plint 1992) e de retorno. Na área estudada foram reconhecidas estratificações cruzadas de peque- no porte e ângulos médios a altos, com grande dispersão de paleocorrentes e vetor médio para SE, possivelmente originadas por correntes de deriva litorânea. (vide Fig. 2A)

A interpretação dos dados de estratificações cruzadas do tipo swaley e de migração de megaondulações permite elaborar um modelo preliminar de paleocorrentes marinhas costeiras para a área estudada. Analisando os vetores de transporte das estratificações cruzadas tipo swaley pode-se concluir que as correntes unidirecionais predominantes durante a atenuação de tempestades tiveram direção norte, provavelmente refletindo uma direção perpendicular à costa e no sentido para o mar.

$O$ vetor médio das estratificações cruzadas por migração de megaondulações indica correntes de deriva litorânea para SE, concordando com uma direção aproximadamente E-W da linha de costa sugerida pelas estratificações cruzadas swaley. A conclusão de uma linha de costa E-W ou NE-SW, com um corpo marinho a norte, confirma o quadro paleogeográfico obtido por Fragoso Cesar et al. (2000), Almeida (2001) e Fambrini (2003) a partir de paleocorrentes de unidades aluviais e, em menor medida, também marinhas costeiras dominadas por ondas e por marés.

CONSIDERAÇÕES FINAIS A exposição do Grupo Santa Bár- 
bara na Sub-Bacia Camaquã Central é representada por uma alternância de depósitos arenosos e rítmicos marinhos/transicionais e depósitos conglomeráticos de leques deltaicos (fan deltas), que compõem ciclos progradacionais-retrogradacionais. Estes ciclos foram interpretados como resultados de variações relativas do nível de base, possivelmente relacionadas em alguma medida a variações relativas do nível do mar, como sugerido por Almeida (2001) para o Grupo Santa Bárbara na Sub-Bacia Camaquã Ocidental, provavelmente associadas a mudanças no equilíbrio entre subsidência e aporte sedimentar, ambos relacionados à evolução tectônica da Bacia do Camaquã.

A progradação dos depósitos de leques aluviais da Formação Rincão dos Mouras foram interpretados como sucessões progradantes resultantes da diminuição da erosão de depósitos mais antigos do Supergrupo Camaquã. Esse evento foi reconhecido por Almeida (2001) na Sub-Bacia Camaquã Ocidental, podendo constituir um elemento de correlação estratigráfica regional.

O contato brusco basal da Formação João Dias constitui a superfície transgressiva do Grupo Santa Bárbara na Sub-Bacia Camaquã Central, caracterizada como trato transgressivo, indicando o avanço do mar durante este período.

A presença de depósitos marinhos costeiros afetados por ondas de tempestades na Formação João Dias contrapõe-se às observações de Faccini et al. (1987) e Paim (1994) que sugeriram um ambiente de planície flúvio-deltaica progradante para estes depósitos, implicando assim na reformulação dos modelos que consi- derem variações do nível do mar para a bacia.

O ambiente marinho para a deposição das unidades do Grupo Santa Bárbara também foi claramente identificado na Sub-Bacia Camaquã Central, com a identificação de depósitos gerados em planícies de marés e de face litorânea a costa-afora, corroborado pela presença de minerais de glauconita.

A evolução estratigráfica e paleoambiental, documentada nos depósitos do Grupo Santa Bárbara mapeados na Sub-Bacia Camaquã Central, mostrou uma notável correlação entre as sucessões das regiões das Minas do Camaquã e de Bom Jardim. Tal correlação baseia-se tanto nas interpretações paleoambientais quanto nas espessuras das unidades estudadas, legitimando, desta forma, a proposta de Robertson (1966) e de Fambrini et al. (1996) de englobar os depósitos da região das Minas do Camaquã no redefinido Grupo Santa Bárbara.

Agradecimentos Este trabalho foi elaborado com auxílio financeiro da FAPESP - Fundação de Amparo à Pesquisa do Estado de São Paulo (Processos 93/03228-7, 98/04510-1, 98/03682-3, 99/008787,00/07510-4 e 01/01439-9), a quem agradecemos o apoio. Ao CNPq pela bolsa de mestrado a G.L.Fambrini. Ao núcleo CPRM/RS pela cessão de fotografias aéreas e mapas. Aos colegas geólogos Ana Paula R. M. Pelosi, Wellington F. Silva Filho, Annamaria R. da Fonseca e Afonso C. R. Nogueira pelo auxílio nos trabalhos de campo e pelas discussões. Aos revisores anônimos e editores da RBG pelas sugestões ao manuscrito.

\section{Referências}

Allen P.A. \& Underhill J.R. 1989. Swaley cross-stratification produced by unidirectional flows, Beneliff Group (Upper Jurassic), Dorset, UK. J. Geol. Soc. London, 146:241-252.

Almeida R.P. 2001. Evolução Tectono-sedimentar da Formação Santa Bárbara na Sub-Bacia Camaquã Ocidental. Dissertação de Mestrado, Instituto de Geociências, Universidade de São Paulo, 161 p.

Blair T.C. 1999. Cause of dominance by sheetflood vs. debris-flow processes on two adjoining alluvial fans, Death Valley, California. Sedimentology, 46:1015-1028.

Blair T.C. \& McPherson J.G. 1994. Alluvial fans and their natural distinction from rivers based on morphology, hidraulic processes, sedimentary processes and facies assemblages. J. Sed. Petrol., Section A, 64:450-489.

Bonhomme M.E. \& Ribeiro M.J. 1983. Datações K-Ar das argilas associadas a mineralizações de cobre da Mina Camaquã e de suas encaixantes. In: SBG, Simp. Sul-Bras. Geol., 1, Atas, 1, p. 82-88.

Carvalho P.F. 1932. Reconhecimento Geológico no Estado do Rio Grande do Sul. Rio de Janeiro, IGMB, Boletim 66, 72 p.

Chafetz H.S. \& Reid A. 2000. Syndepositional shallow-water precipitation of glauconitic minerals. Sediment. Geology, 136:29-42.

Cheel R.J. \& Leckie D.A. 1992. Coarse-grained storm beds of the Upper Cretaceous Chungo Member (Wapiabi Formation), southern Alberta, Canada. J. Sed. Petrol., 62:933-945.

Collinson J.D. \& Thompson D.B. 1989. Sedimentary structures. London , Unwin Hyman, 207 p.

De Raaf J.F.M., Boersma J.R., van Gelder A. 1977. Wave-generated structures and sequences from a shallow marine succession, Lower Carboniferous, County Cork, Ireland. Sedimentology, 24:451-483.

Dott Jr. R.H. \& Bourgeois J. 1982. Hummocky stratification: significance of its variable sequences. Geol. Soc. Am. Bull., 93:663-680.

Duke W.L, Arnott R.W.C., Cheel R.J. 1991. Storm sandstones and hummocky cross-stratification: new evidences on a stormy debate. Geology, 19: 625-628.

Faccini U.F., Paim P.S.G., Fragoso-Cesar A.R.S. 1987. Análise faciológica das molassas brasilianas na região das Minas do Camaquã, Eopaleozóico do RS. In: SBG, Simp. Sul-Bras. Geol., 3, Atas, 1, p. 75-91.

Fambrini G.L. 1998. O Grupo Camaquã (Transição ProterozóicoFanerozóico) na região das Minas do Camaquã, RS: análise estratigráfica de fácies, proveniência e paleocorrentes. Dissertação de Mestrado, Inst. Geoc., USP, 182 p.

Fambrini G.L. 2003. O Grupo Santa Bárbara (Neoproterozóico III) a norte do rio Camaquã, Rio Grande do Sul, Brasil. Tese de Doutoramento, Inst. Geoc., USP, 243 p.

Fambrini G.L., Fragoso-Cesar A.R.S., Riccomini C., Janikian L., Paes de Almeida R., Pelosi A.P.M.R. 2001. Tectônica extensional sindeposicional na Formação Santa Bárbara, Bacia do Camaquã, RS (Neoproterozóico III-Cambriano Inferior). In: SBG/ABGP, Simp. Nac. Estudos Tectônicos, 8, Anais, p. 149-150.

Fambrini G.L., Fragoso-Cesar A.R.S., Silva Filho W.F., Teixeira G., Sayeg H.S., Machado R. 1998. Análise estratigráfica de fácies, proveniência e paleocorrentes do Grupo Camaquã (transição ProterozóicoCambriano) na Mina Uruguai e suas implicações na evolução tectono- 
sedimentar da Bacia do Camaquã, RS. Boletim IG-USP, Série Científica, 29:39-69.

Fambrini G.L., Janikian L., Paes-de-Almeida R., Fragoso-Cesar A.R.S., Fonseca A.R. 2002. Seqüências da Formação Santa Bárbara (Neoproterozóico III-Cambriano Inferior) na Sub-Bacia Camaquã Central, RS. In: SBG, Cong. Bras. Geol., 41, Anais, p. 660.

Fambrini G.L., Saes G.S., Fragoso-Cesar A.R.S., Silva Filho W.F., Sayeg H.S., Teixeira G., Machado R., McReath I., Ribeiro de Almeida T.I., Phillip R.P. 1996. Sistemas costeiros da Formação Santa Bárbara, Bacia do Camaquã, RS (transição Proterozóico-Fanerozóico): registro preliminar da sedimentação em ambiente de águas rasas dominado por ondas. In SBG Núcleos Bahia/Sergipe, Congresso Brasileiro de Geologia, 39, Bol. Res. Exp., 2, p. 204-206.

Fragoso-Cesar A.R.S., Almeida R.P., Fambrini G.L., Pelosi A.P.M.R., Janikian L. 2003. A Bacia Camaquã: um sistema intracontinental anorogênico de rifts do Neoproterozóico III-Eopaleozóico no Rio Grande do Sul. In: SBG, Encontro Estrat. Rio Grande do Sul-Escudos e Bacias, 1, Anais, p. 139-144.

Fragoso-Cesar A.R.S., Fambrini G.L., Paes de Almeida R., Pelosi A.P.M.R., Janikian L., Riccomini C., Machado R., Nogueira A.C.R., Saes G.S. 2000. The Camaquã extensional basin: Neoproterozoic to early Cambrian sequences in southernmost Brazil. Rev. Bras. Geoc., 30:438-441.

Fragoso-Cesar A.R.S., Fambrini G.L., Riccomini C., Janikian L., Paes de Almeida R., Pelosi A.P.M.R., Machado R. 2001. Estruturas induzidas por abalos sísmicos na Seqüência Santa Bárbara (Neoproterozóico III-Eocambriano), Bacia do Camaquã, RS: o exemplo do Passo da Capela. Rev. Bras. Geoc., 31:155-162.

Gonzalez M.A. \& Teixeira G. 1980. Considerações sobre a estratigrafia e ambientes de sedimentação da região das Minas do Camaquã e Jazida Santa Maria -RS. In: SBG, Cong. Bras. Geol., 31, Anais, 3:15131524.

Janikian L. 2001. Evolução Paleoambiental do Grupo Camaquã na região de Bom Jardim, Sub-Bacia Camaquã Central, RS. Dissertação de Mestrado, Inst. Geoc., USP, 158 p.

Lowe D.R. 1982. Sediment gravity flows: II. Depositional models with special reference to the deposits of high-density turbidity currents. J. Sed. Petrol., 52:279-297.

McPherson J.G., Shanmugan G., Moiola R.J. 1987. Fan-deltas and braid deltas: varieties of coarse-grained deltas. Geol. Soc. Am. Bull., 99:331340 .

Miall A.D. 2000. Principles of sedimentary basin analysis. $3^{\text {nd }}$ ed., Springer-Verlag, New York, 616 pp.

Myrow P.M. \& Southard J.B. 1996. Tempestite deposition. J. Sedim.
Res., 66:875-887.

Netto R.G., Paim P.S.G., Rosa C.L.M. 1992. Informe preliminar sobre a ocorrência de traços fósseis em sedimentitos das Bacias do Camaquã e Santa Bárbara. In: SBG/UNISINOS, Workshop Bacias Molássicas Bras., 1, Bol. Res. Exp., p. 90-96.

Odin G.S. 1988. Green Marine Clays. Developments in Sedimentology 45, Elsevier Amsterdam, 112 pp.

Paim P.S.G. 1994. Depositional Systems and Paleogeographical Evolution of the Camaquã and Santa Bárbara Basins, Brazil. Phil. Doctor Thesis, University of Oxford. v.I, 277 p. (inédito).

Paim P.S.G., Chemale Jr. F., Lopes R.C. 2000. A Bacia do Camaquã. In: M. Holtz,. L.F. De Ros (eds.) Geologia do Rio Grande do Sul.

Paim P.S.G., Faccini U.F., Netto R.G., Nowatzki, C.H. 1992. Estratigrafia de seqüências e sistemas deposicionais das bacias do Camaquã e Santa Bárbara, Eopaleozóico do RS (Brasil). Correlación Geologica, 9:41-45.

Ribeiro M., Bocchi P. R., Figueiredo Filho P. M., Tessari R.I. 1966. Geologia da Quadrícula de Caçapava do Sul, Rio Grande do Sul. Rio de Janeiro, DNPM/DFPM, Boletim 127, 232 p.

Robertson J.F. 1966. Revision of stratigraphy and nomenclature of rock units in Caçapava-Lavras Region. Notas e Estudos, 1(2):41-54.

Steel R.J., Maehle S., Nilsen H., RØe S.L., Spinnangar Å. 1977. Coarsenigupward cycles in the alluvium of Hornelen Basin (Devonian), Norway: sedimentation response to tectonic events. Geol. Soc. Am. Bull., 88:1124-1134.

Van Houten F.B. \& Purucker M.E. 1985. On the origin of glauconite and chamositic granules. Geo-Marine Letters, 5:47-49.

Walker R.G. 1992. Facies, facies models and modern stratigraphic concepts. In: R.G Walker. \& N.P. James (eds): Facies Models - Response to Sea-level Change, Geological Association of Canada Geotext 1, Waterloo, pp. 1-14.

Walker R.G. \& Plint A.G. 1992. Wave- and storm-dominated shallow marine systems. In: R.G. Walker and N.P. James (eds). Facies Models: Response to Sea-level Change, Geological Association of Canada Geotext 1, Waterloo, pp. 219-238.

Yagishita K., Arakawa S., Taira A. 1992. Grain fabric of hummocky and swaley cross-stratification. Sedim.Geol., 78:181-189.

Manuscrito A-1467

Recebido em 11 de agosto de 2003

Revisão dos autores em 25 de abril de 2005 Revisão aceita em 05 de maio de 2005 